\title{
Recent Approaches to the Chemical Synthesis of Sugar Nucleoside Diphosphates
}

\section{糖ヌクレオシドニリン酸の化学合成に向けた最近のアプローチ}

\author{
Tanaka, Hidenori \\ Oceanography Section, Science Research Center, Kochi University, 2-17-47 Asakurahonmachi, Kochi-shi, Kochi, 780-8073, Japan \\ FAX: +81-88-888-8035, E-mail: htanaka@kochi-u.ac.jp \\ (Received on September 30, 2014, accepted on October 17, 2014)
}

Key Words: glycosyltransferase, sugar nucleotide, sugar nucleoside diphosphate, pyrophosphate, glycosylation, phosphoramidite

\begin{abstract}
Sugar nucleotides are important intermediates in carbohydrate metabolism and function as activated glycosyl donors for the biosynthesis of oligosaccharides. This review focuses on recent progress in the chemical synthesis of sugar nucleoside diphosphates.
\end{abstract}

\section{A. Introduction}

Chemical synthesis of naturally occurring complex oligosaccharides is increasingly more accessible due to recent progress in the development of protection (1) and glycosylation methods (26). Despite these advances, such synthesis is still time-consuming since it requires multiple steps, including protection-deprotection manipulations and region-/stereo-selective glycosylations. To overcome this limitation, the Seeberger research group has worked intensively toward an automated oligosaccharide synthesis $(7,8)$ and developed the first commercial fully automated synthesizer. Synthetic approaches for complex oligosaccharides using glycosyltransferase reactions $(9,10)$ are also becoming more feasible because a large number of glycosyltransferase genes have been cloned (11). The enzymes that use sugar nucleotides as glycosyl donors are able to glycosylate acceptor molecules with regio- and stereo-selectively in the absence of protecting groups.

This review describes recent progress in the chemical synthesis of sugar nucleoside diphosphates (sugar NDPs), which function as activated donors in most glycosyltransferase-catalyzed glycosylations (12). Although other sugar nucleotides, such as members of the cytidine-5'-monophospho- $N$-acetylneuraminic acid (CMPsialic acid) family, are also important in a number of biological events, the synthetic approaches for only sugar NDPs are detailed here. In the following discussion, both methods by pyrophosphate (diphosphate) formation and glycosylation for sugar NDP synthesis are described (Fig. 1).
要 約

糖ヌクレオチドは糖質代謝で重要な中間体であり、糖鎖 の生合成において活性な糖供与体として用いられている。本 総説では糖ヌクレオシド二リン酸の化学合成の最近の進展に ついて論じる。

A. はじめに

近年の保護基(1)、グリコシル化法（2-6）の開発により、 天然に存在する複雑な糖鎖の化学合成が以前よりも容易に行 えるようになってきたが、保護・脱保護、位置および立体選 択的グリコシル化反応を含む多段階を必要とすることからそ の合成には未だ多くの労力と時間がかかる。この欠点を解決 するべくSeebergerのグループは糖鎖自動合成の研究を精力 的に行い $(7,8)$ 、世界初の市販型完全自動合成機を開発した。 一方、数多くの糖転移酵素遺伝子のクローニング(11）が進 んでいることから糖転移酵素反応を用いた合成アプローチも より実現可能なものになってきた $(9,10)$ 。糖供与体として糖 ヌクレオチドを利用する本酵素は受容体分子を位置および立 体選択的に配糖化することができる。

本稿では、多くの糖転移酵素が基質とする糖ヌクレシド 二リン酸（糖NDP）の化学合成についての最近の動向を紹 介したい(12)。もちろんCMP シアル酸ファミリーなどの他 の糖ヌクレオチドもさまざまな生命現象において重要ではあ るが、ここでは糖NDPの合成アプローチについてのみ論じ る。以後の議論では、糖NDPのピロリン酸（二リン酸）結 合形成による合成法とグリコシル化による合成法を示す（図 $1)$ 。 


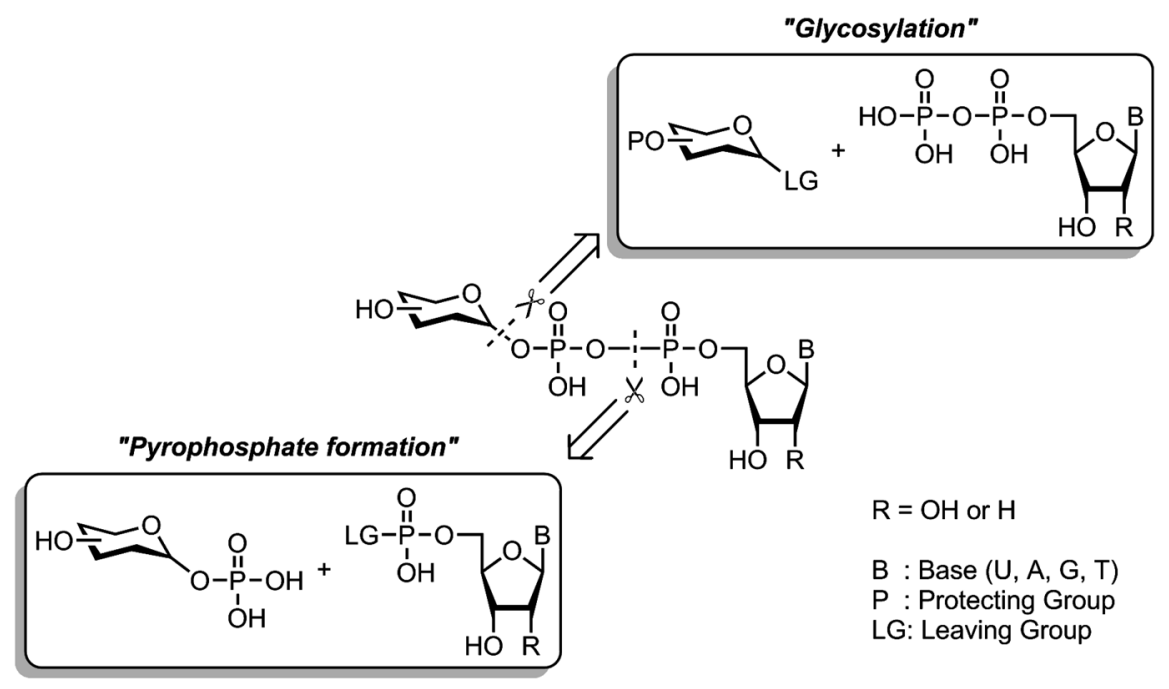

Fig. 1. General approaches to the chemical synthesis of sugar NDPs.
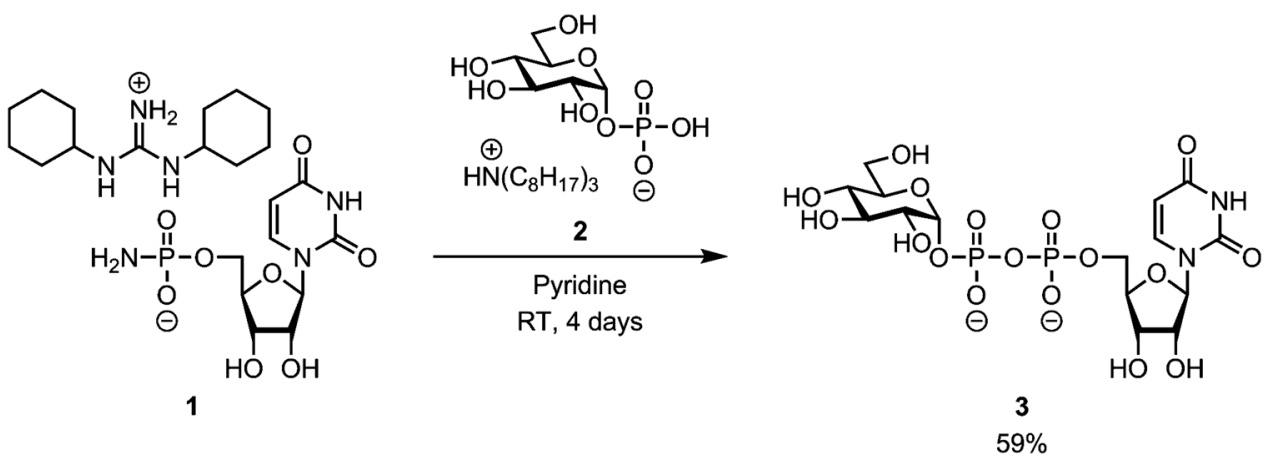

Fig. 2. Synthesis of glucose UDP (3) with phosphoramide-activated UMP (1).

B. Synthesis of Sugar NDPs by Pyrophosphate Formation between Sugar 1-Phosphate and Activated Nucleoside-5'-Monophosphate (NMP)

\section{B-1. Using Phosphoramide}

Carbodiimides are powerful reagents for pyrophosphate formation, but disrupt for hetero-phosphate condensation reactions (13). This problem can be solved by the cross-coupling of nucleophilic phosphates with electrophilic phosphates that contain a leaving group on the phosphorus atom. Following this idea, the Khorana group first reported the preparation of uridine-5'-phosphoramide 1 (14) for use in the synthesis of UDP- $\alpha$-D-glucose 3 (Fig. 2) (15). This activated UMP 1 is readily prepared by the reaction of UMP with $N, N^{\prime}$-dicyclohexylcarbodiimide (DCC) and ammonia water in pyridine. However, the disadvantage of phosphoramide is its low solubility in organic solvents, a property that reduces the efficiency of pyrophosphate formation.

\section{B-2. Using Phosphoromorpholidate}

The Khorana group also developed an improved pyrophosphate formation by the replacement of amine with morpholine as a
B. 糖一リン酸とヌクレオシドモノリン酸 (NMP) とのピ ロリン酸結合形成による糖NDPの合成

B-1. ホスホロアミドを用いる方法

カルボジイミドはピロリン酸結合形成において効果的な 試薬であるが、ヘテロなリン酸縮合反応には適してはいない （13）。この問題はリン原子に脱離基を有する求電子体を用い たクロスカップリングにより解決することができる。そこ で、Khoranaのグループは初めてウリジンホスホロアミド1 を調製し(14)、UDP- $\alpha$-D-グルコース3の合成に応用した（図 2）（15）。この活性化されたUMP1 はピリジン中DCC とアン モニア水を作用させることにより容易に調製可能である。し かしながら、ホスホロアミドは有機溶媒に対して溶解度が小 さく、ピロリン酸結合形成の効率を低下させるため、その利 用には制限がある。

B-2. ホスホロモルホリデートを用いる方法

Khoranaのグループは次に溶解性と反応性の向上を狙 い、脱離基をアミンからモルホリンに置換することでピロリ 


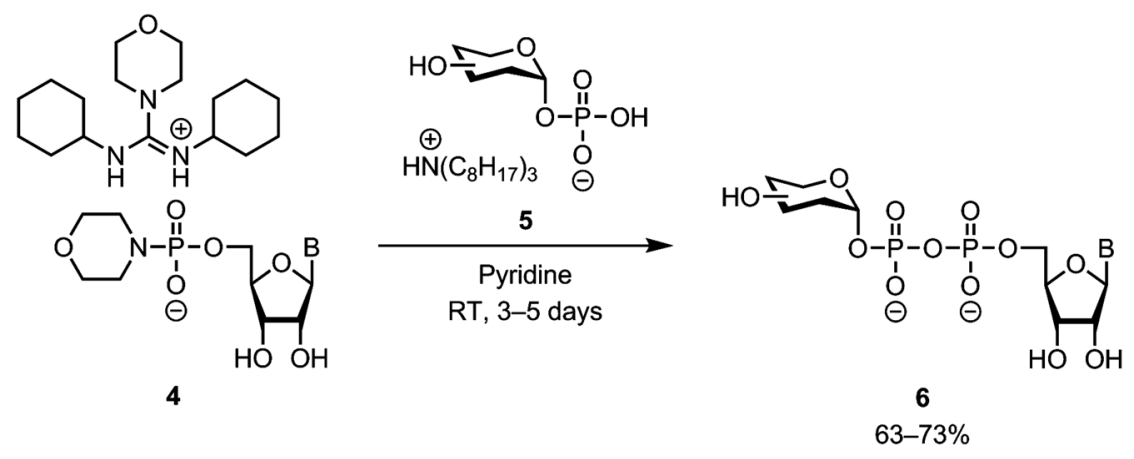

Fig. 3. Synthesis of sugar NDPs (6) with phosphoromorpholidate-activated NMPs (4).

leaving group of phosphate to increase its solubility and reactivity (16). This activated phosphate molecule 4 , which is referred to as phosphoromorpholidate, has been widely used for the synthesis of natural and unnatural sugar NDPs (Fig. 3). For example, UDP- $\alpha$ D-fluorinated sugars as enzyme active site probes (17), and UDP$\alpha$-D- $N$-acetylglucosamine derivatives as inhibitors (18), have been synthesized. Typically, the method using phosphoromorpholidates is not necessary for protecting hydroxyl and amino groups on the sugar and nucleoside moieties. Meanwhile, Kosma et al. utilized acetylated heptose 1-phosphates to improve the solubility of sugar 1-phosphates in organic solvents and synthesized NDP-heptoses in excellent yields $(19,20)$. Although many sugar NDPs have been synthesized using the phosphoromorpholidate method, the condensation reactions require about 5 days to complete.

\section{B-3. Effect of Additives}

$1 H$-tetrazole 9 has been used in oligonucleotide synthesis as an additive for phosphoramidite activation (21). Wong et al. demonstrated that the addition of $1 H$-tetrazole 9 markedly accelerated pyrophosphate formation during sugar NDP synthesis, which was complete within 2 days, and also increased the reaction yields (22). In this coupling reaction, $1 H$-tetrazole 9 would act not only as an acidic catalyst, but also as a nucleophilic catalyst. Recently, Kahne et al. reported that $N$-methylimidazolium chloride $\mathbf{1 0}$ was a much more effective catalyst than $1 H$-tetrazole 9 to dramatically enhance pyrophosphate formation (Fig. 4) (23). The authors suggested that the increased efficiency of pyrophosphate formation was due to the in situ generation of a highly reactive intermediate 12 containing $N$-methylimidazole as a leaving group (phosphoro$N$-methylimidazolide), which is discussed in detail below. As an alternative approach, Sun et al. developed an improved activation method involving the combination of 4,5-dicyanoimidazole and phosphoropiperidate (24).

\section{B-4. Using Phosphorimidazolide}

In addition to phosphoromorpholidate, phosphorimidazolide has also been utilized for pyrophosphate formation. This com-
ン酸結合形成効率を改善した(16)。ホスホロモルホリデー トと呼ばれるこの活性なリン酸分子 4 は天然型、ならびに非 天然型糖NDPの合成に広く用いられた（図3）。例えば、酵 素活性部位のプローブとして用いることができるUDP- $\alpha$-Dフッ化糖 (17)、酵素阻害剂として働くUDP- $\alpha-D-N-$ ア セチル グルコサミン誘導体(18) の合成に応用された。ホスホロモ ルホリデートを用いる本合成法は糖やヌクレオシドの水酸 基・アミノ基を保護する必要がない。一方、Kosma らは糖一 リン酸の有機溶媒に対する溶解性の向上を狙いアセチル化へ プトースーリン酸を用いることで、極めて高い収率でへプ トースNDPの合成に成功した $(19,20)$ 。モルホリデート法で さまざまな糖NDPが合成されてきたが、その縮合反応の完 結にはおよそ5日必要であった。

\section{B-3. 添加剂の効果}

1H-テトラゾール9はオリゴヌクレオチド合成でホスホ ロアミダイトの活性化における添加剤として使用されている (21)。Wong らは $1 H$-テトラゾール9の添加が糖NDP合成に おいてピロリン酸結合形成を著しく促進させることを明らか にした $(22)$ 。本縮合反応は 2 日以内で完結し、さらには反応 収率も向上したことから、1H-テトラゾール9が単なる酸触 媒だけでなく、求核触媒として作用していることが示唆され た。最近、KahneらはN-メチルイミダゾール塩酸塩 $\mathbf{1 0}$ が $1 H-$ テトラゾール9よりもピロリン酸結合形成を劇的に促進する 触媒であることを報告した（図4）（23）。ピロリン酸結合形 成効率の向上は系中で $N$-メチルイミダゾールを脱離基とし て有する高反応性中間体 12 (ホスホロ-N-メチルイミダゾリ ド）の生成によるものであることを筆者らは提案している。 ホスホロ-N-メチルイミダゾリドについては後に詳しく述べ る。そのほかのアプローチとして、Sunらによって開発され たジシアノイミダゾールとホスホロピペリデートの組み合わ せによる活性化法がある(24)。

\section{B-4. ホスホロイミダゾリドを用いる方法}

ホスホロモルホリデートに加え、温和な条件下 CDI 14 を作用させることで調製可能なホスホロイミダゾリド $(25)$ 

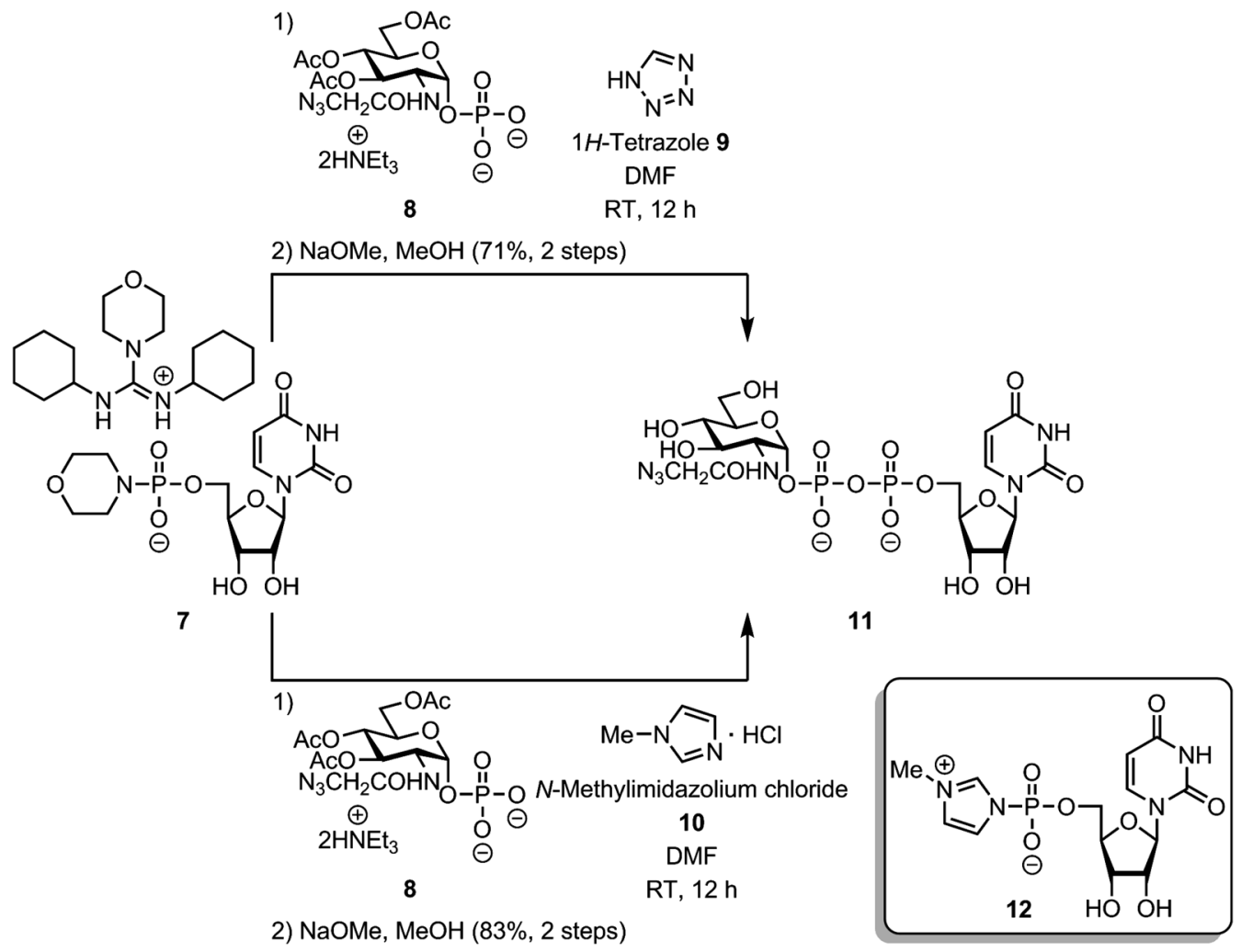

Fig. 4. Improvement of pyrophosphate formation by addition of $1 \mathrm{H}$-tetrazole (9) versus $\mathrm{N}$-methylimidazolium chloride (10).

pound can be prepared by the treatment of $1,1^{\prime}$-carbonyldiimidazole (CDI) 14 under mild conditions (25). Öhrlein et al. utilized imidazolidate-activated NMPs $\mathbf{1 5}$ for the synthesis of NDP- $\beta$-Lfucose analogs 17 (Fig. 5) (26). The use of morpholidate-activated GMP has been reported to increase reaction times and generate large amounts of undesired byproducts that are difficult to remove. Phosphorimidazolide is more active than the combination of phopsphoromorpholidate and $1 H$-tetrazole. Although this method of pyrophosphate formation has been widely applied to the synthesis of many types of sugar NDPs $(27,28)$, it often suffers from poor reproducibility due the difficulty in maintaining anhydrous reaction conditions because of the requirement for hygroscopic substrates and reagents. Recently, Hindsgaul et al. accomplished the chemical synthesis of sugar NDPs in water (Fig. 6) (29). The key to their method was the in situ generation of an 2-imidazolyl-1,3dimethylimidazolinium ( $\mathrm{ImIm}$ ) intermediate $\mathbf{2 3}$ through the reaction of 2-chloro-1,3-dimethylimidazolinium chloride (DMC) 19 and imidazole 20. As the ImIm intermediate $\mathbf{2 3}$ was able to activate the phosphate groups in NMPs into phosphorimidazolide in water, this method was used to successfully synthesize several sugar NDPs 22 in a one-pot synthetic fashion by mixing sugar 1-phosphates 21 with in situ generated imidazolide-activated NMPs 24. Even though high yields were not obtained $(30,31)$, the advantage
もまたピロリン酸結合形成に広く用いられている。NDP- $\beta$-Lフコース17の合成でÖhrlein らは活性 NMP イミダゾリド体 15 を利用した（図 5）（26）。GMPホスホロモルホリデート体 を用いた場合は反応が遅く、さらに除去が難しい副産物を大 量に生成することが報告されている。また、ホスホロイミダ ゾリドはホスホロモルホリデートと $1 H$-テトラゾールとの組 み合わせと比べてより活性である。CDIを用いた本方法はさ まざまな糖NDP合成に応用されてきたが $(27,28) 、$ 吸湿性の 基質や試薬を用いるために脱水条件を保つのが難しいこと からしばしば再現性に問題を抱えていた。最近、Hindsgaul らによって水中での糖ヌクレオチドの化学合成が達成され た（図 6）（29）。本方法で鍵となったのが、DMC 19 とイミダ ゾール 20 から ImIm 中間体 23 を系中で発生させたことであっ た。 ImIm中間体 23 は水中でNMPのリン酸基をホスホロイ ミダゾリドへ活性化できたため、彼らは系中で発生した活性 NMP イミダゾリド体 24 を直接糖一リン酸 21 との縮合に供す るワンポット法を利用することで数種の糖NDP 22 の合成に 成功した。本合成法の収率は高くはないが $(30,31)$ 、合成操 


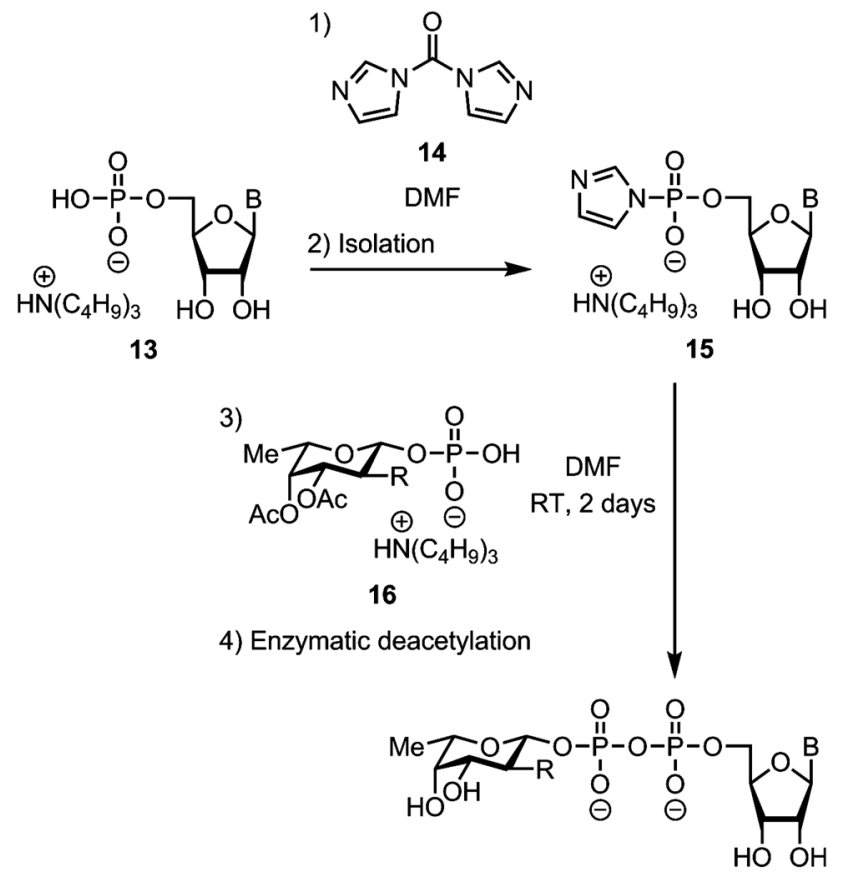

17

$53-86 \%, 4$ steps
Fig. 5. Synthesis of NDP- $\beta$-L-fucose analogs (17) with phosphorimidazolide-activated NMPs (15) by using CDI activation method.

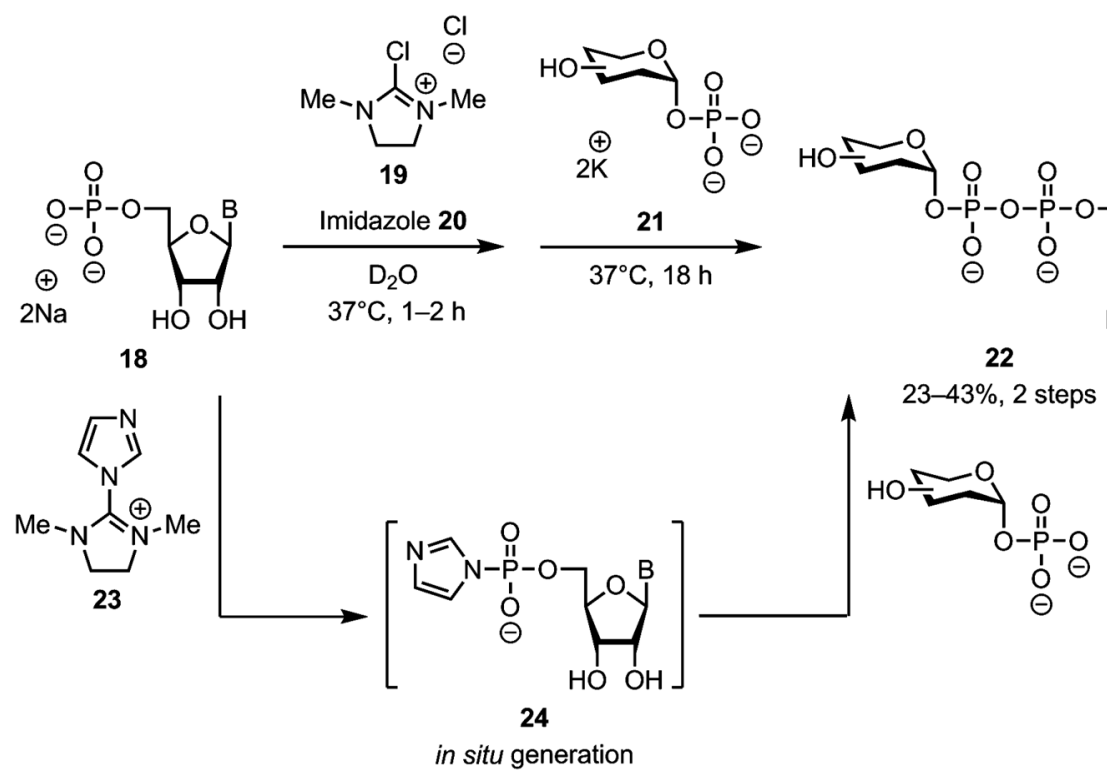

Fig. 6. Synthesis of sugar NDPs (22) with phosphorimidazolide-activated NMPs (24) by using ImIm activation method.

of this synthetic procedure is that it is relatively simple and can be performed with commercially available inorganic salts of NMPs (sodium form) and sugar 1-phosphates (potassium form). Additionally, the synthesized sugar NDPs in the reaction mixture can be directly used as a source of glycosyl donors without purification for glycosyltransferase reactions on a milligram scale.

\section{B-5. Using Phosphoro- $N$-methylimidazolide}

The above-mentioned enhancement of pyrophosphate for-
作が単純であること、入手可能な無機塩体である NMP（ナ トリウム体)、糖一リン酸（カリウム体）を用いて行えるこ とが強みである。さらに、ミリグラムスケールであれば反応 混合物中に存在する合成糖NDPを精製せずに直接糖供与体 として糖転移反応に用いることが可能である。

B-5. ホスホロ-N-メチルイミダゾリドを用いる方法

上述した $N$-メチルイミダゾール塩酸塩 10 の添加による 


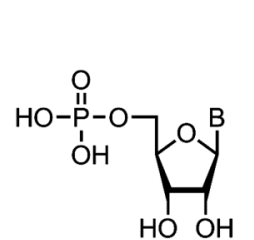

25
1) $T F A c_{2} \mathrm{O}, \mathrm{N}\left(\mathrm{C}_{2} \mathrm{H}_{5}\right)_{3}$, Dimethylaniline

$\mathrm{MeCN}, 0-5^{\circ} \mathrm{C}, 15 \mathrm{~min}$

2) N-Methylimidazole, $\mathrm{N}\left(\mathrm{C}_{2} \mathrm{H}_{5}\right)_{3}$

$\mathrm{MeCN}, 0-5^{\circ} \mathrm{C}, 15 \mathrm{~min}$

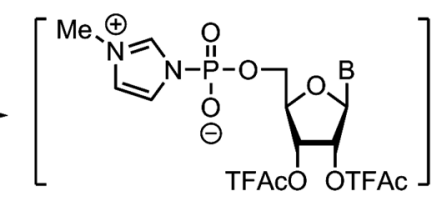

26

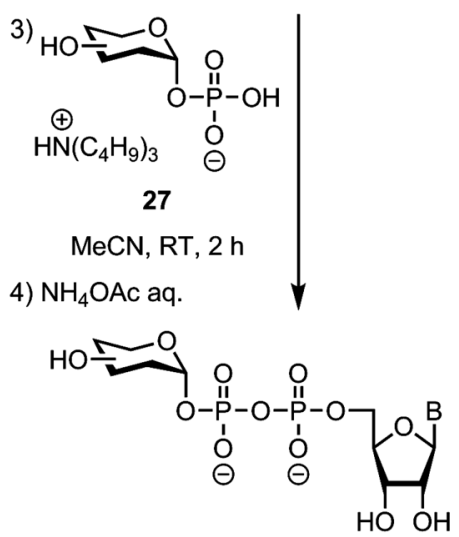

28

$26-48 \%, 4$ steps

Fig. 7. Synthesis of sugar NDPs (28) with phosphoro- $N$-methylimidazolide-activated NMPs (26).

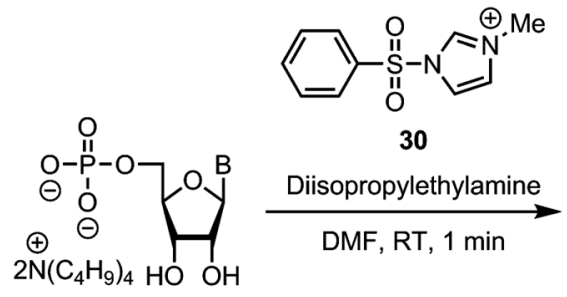

29

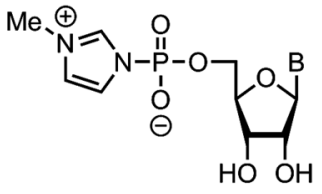

31

Fig. 8. Activation of NMPs (29) with a novel reagent (30).

mation by the addition of $N$-methylimidazolium chloride $\mathbf{1 0}$ was triggered by the phosphoro- $N$-methylimidazolide 12 that was generated in situ as a highly reactive intermediate (23). Bogachev et al. first reported the use of this intermediate in nuclesoside triphosphate (NTP) synthesis (32), and their method was later adapted for the synthesis of dinucleoside polyphosphates (33) and sugar NDPs $(34,35)$. Although the $N$-methylimidazolide-activated species $\mathbf{2 6}$ is extremely reactive and the coupling reaction can be completed within $2 \mathrm{~h}$ at room temperature, a number of troublesome procedures, including the trifluoroacetylation of NMP 25 and incorporation of $\mathrm{N}$-methylimidazole, are needed for the preparation of the intermediate (Fig. 7). More recently, Taylor et al. developed a new phosphate-selective reagent 30 that readily converts into $N$ methylimidazolide-activated intermediate 31 (Fig. 8) (36). Using this reagent, they successfully synthesized not only sugar NDP, but also symmetric and asymmetric dinucleoside polyphosphates.
反応促進効果は、系中に発生した高反応性中間体であるホ スホロ-N-メチルイミダゾリド 12 にるものであった $(23) 。$ BogachevらはNTP合成においてこの中間体を初めて報告し (32)、その後彼らの方法はジヌクレオシドポリリン酸 (33)、 糖 NDP 合成 $(34,35)$ へと応用された。ホスホロ-N-メチルイ ミダゾリド種 26 は非常に反応性が高く、その縮合反応は室 温下 2 時間以内で完結するが、この中間体の調製には酸性型 NMPのトリフルオロアセチル化、続く $N$-メチルイミダゾー ルの導入を含む煩雑な操作が必要であった（図 7)。つい最近、 Taylorらによって活性 $N$-メチルイミダゾリド中間体 $\mathbf{3 1}$ へ簡 便に変換できるリン酸基選択的な試薬 $\mathbf{3 0}$ が開発された（図 8）。本反応剤を用いることで、糖NDPだけでなく、対称・ 非対称のジヌクレオシドポリリン酸のワンポット合成にも成 功している。 


\section{B-6. cycloSal Chemistry}

The Meier group developed a novel approach using a cyclosaligenyl (cycloSal) group (37) to sugar NDP synthesis that differs from P-N chemistry based on phosphoromorpholidate and phosphorimidazolide (38). In this method, cycloSal is used not only as a protecting group of trivalent phosphorous, but also as a leaving group for pentavalent phosphorous. The cycloSal on phosphorous (V) first reacts with a phosphate nucleophile $\mathbf{3 5}$ along with cleavage of the phenolic $\mathrm{P}-\mathrm{O}$ bond, which is followed by the spontaneous elimination of the cycloSal group to give the pyrophosphate product 37 (Fig. 9). cycloSal protected NMPs 34 are easily prepared by reaction of the hydroxyl group located at the $5^{\prime}$ position of nucleosides $\mathbf{3 2}$ with cycloSal phosphorochloridite $\mathbf{3 3}$ and oxidation of the resulting phosphites. Notably, the coupling of cycloSal protected NMPs with sugar 1-phosphates gave relatively high yields compared with $\mathrm{P}-\mathrm{N}$ chemistry-based synthetic approaches $(39,40)$. However, the synthesis of TDP- $\alpha$-L-6-deoxyaltrose 39 could not be achieved using this method, as the product was decomposed by the intramolecular attack of the generated hydroxyl group at the 3 position of sugar under deacetylation conditions (Fig. 10) (41).

\section{B-7. Using Phosphoramidite}

The phosphoramidite method (21), which is widely used for RNA and DNA synthesis, was applied to the synthesis of naturally occurring UDP- $\alpha$-D- $N$-acetylglucosamine and its derivatives 44 by the van der Marel group (Fig. 11) (42). Using a similar procedure as used for oligonucleotide synthesis, uridine phosphoramidite $\mathbf{4 1}$
B-6. シクロサリザニル (cycloSal) 化学

ホスホロモルホリデート、ホスホロイミダゾリドを利用

した P-N化学とは異なるcycloSal基(37) を用いた新たな糖 NDPの合成アプローチ(38) がMeierのグループによって開 発された。本方法では、cycloSalを三価のリンの保護基とし てだけでなく五価のリンの脱離基として用いる。五価リン上 の cycloSal 基は始めに求核種 $\mathbf{3 5}$ との反応でフェノール性 $\mathrm{P}-\mathrm{O}$ 結合の切断を導き、続く自発的な cycloSal 基の脱離によりピ ロリン酸生成物 37 をえる（図9）。cycloSal保護NMP 34 は ヌクレオシド32の 5 位水酸基と cycloSal ホスホロクロリド 33 との反応、生じたホスファイトの酸化によって容易に調製が 行える。糖一リン酸とのカップリング反応は $\mathrm{P}-\mathrm{N}$ 化学を用い た合成法と比べて良好な収率を与えた $(39,40)$ 。しかしなが ら、本方法による TDP- $\alpha$-L-6-デオキシアルトロース 39の合 成は脱アセチル化で生じた 3 位糖水酸基の分子内環化によっ て生成物の分解を導くために困難であった（図 10）(41）。

\section{B-7. ホスホロアミダイトを用いる方法}

van der MarelのグループはDNA、RNA 合成に広く用い られているホスホロアミダイト法(21) を天然型UDP- $\alpha-D-N$ アセチルグルコサミンとその誘導体 44 の合成に応用した（図 11）(42）。オリゴヌクレオチド合成の操作と同様に、ジシア ノイミダゾール存在下ウリジンホスホロアミダイト 41 と糖

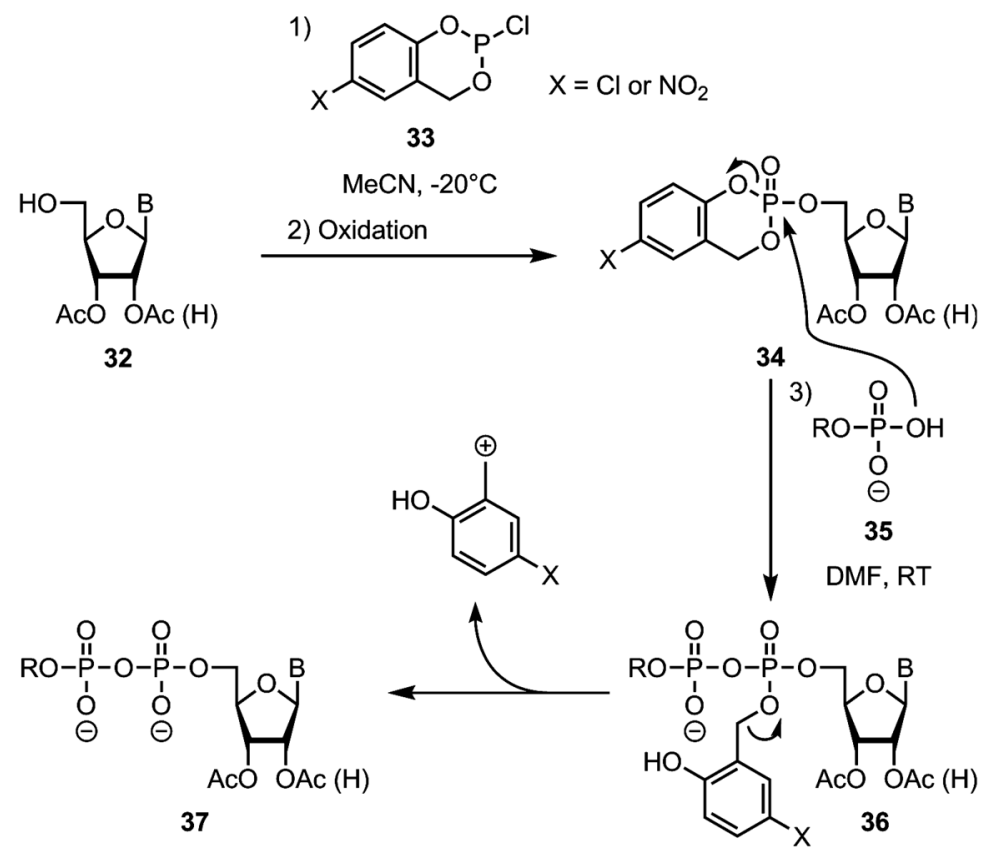

Fig. 9. Pyrophosphate formation by using cycloSal chemistry. 


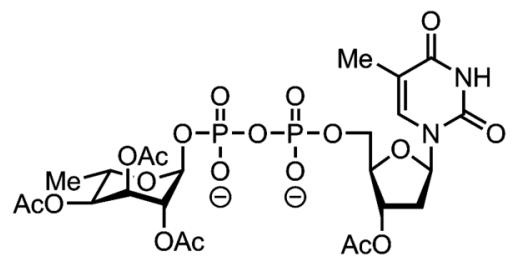

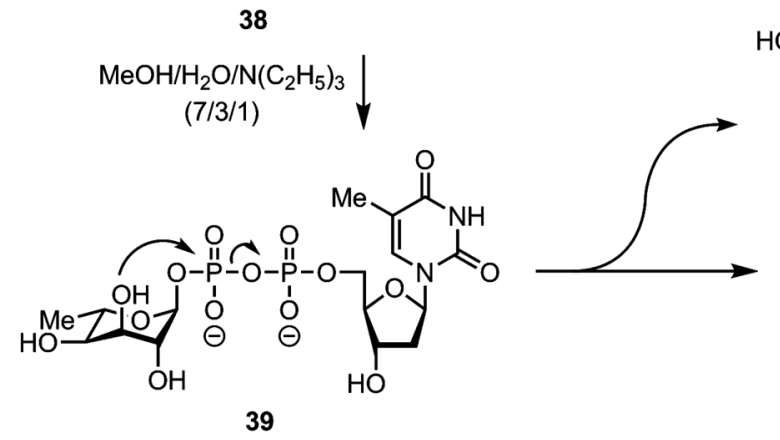<smiles>Cc1cn(C2C(O)C3OC2C3OP(=O)(O)O)c(=O)[nH]c1=O</smiles>

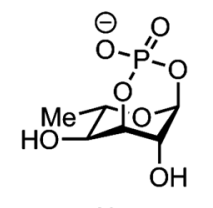

Fig. 10. Decomposition of TDP- $\alpha$-L-6-deoxyaltrose (39).

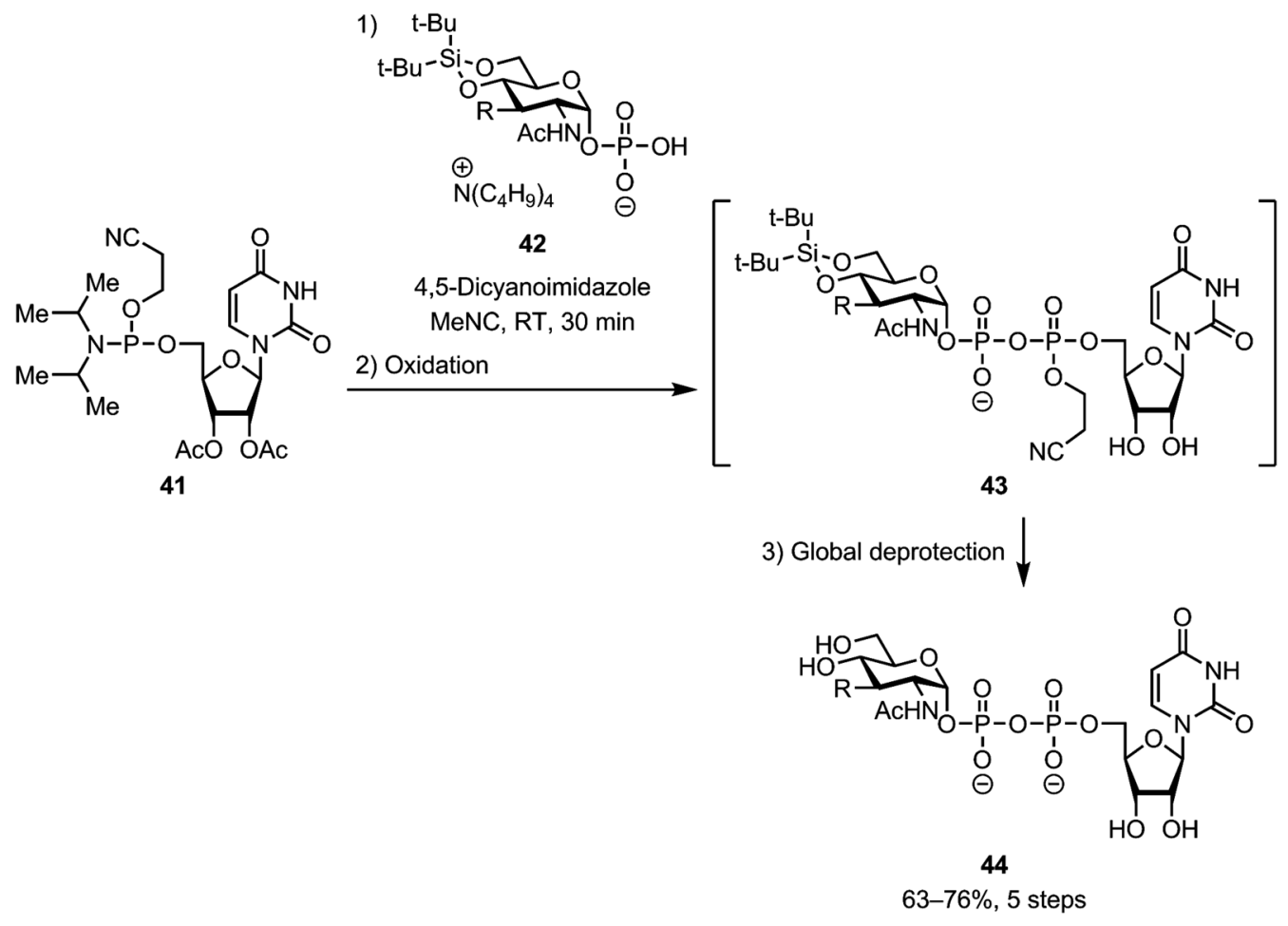

Fig. 11. Synthesis of UDP- $\alpha$-D- $N$-acetylglucosamine derivatives (44) with uridine phosphoramidite (41).

was coupled with sugar 1-phosphate $\mathbf{4 2}$ in the presence of 4,5-dicyanoimidazole, followed by the oxidation to phosphotriester $\mathbf{4 3}$ and deprotection to give the desired products $\mathbf{4 4}$ in high yields (63-76\%). Even though nucleoside phosphoramidites must be prepared from nucleosides in at least three reaction steps, the main advantage of this synthetic method is the theoretical inhibition of the formation of homo-coupled NMP dimers, which are often difficult to separate from the desired product. The modified sugar NDPs
一リン酸 42 との縮合を行い、続くリン酸トリエステル 43 へ の酸化と脱保護によって目的生成物 44 を高い収率（63-76\%）

にて得た。ヌクレオシドホスホロアミダイトの調製はヌクレ オシドから少なくとも三段階必要であるが、本合成法は通 常目的生成物と分離しにくいNMPの自己縮合体の形成を理 論的に排除することができる点で優れている。合成した糖 
44 would be used as chain terminators for the enzyme mediatedpolymerization.

\section{Synthesis of Sugar NDPs by Glycosylation of NDP}

Glycosylation of NDP is a direct method of sugar NDP synthesis because monosaccharide substrates are more readily available compared with sugar 1-phosphates for above-mentioned methods involving pyrophosphate formation. The Hindsgaul group first developed a direct approach for sugar NDP synthesis $(43,44)$. As shown in Fig. 12, O-trimethylsilyl (TMS)-protected glycosyl iodides 46, which are easily prepared from free monosaccharides 45, were coupled to UDP tetrabutylammonium salt $\mathbf{4 7}$ and the resulting products were desilylated with tetrabutylammonium fluoride (TBAF) to give the corresponding sugar UDPs 48 in good yields (30-49\%). Although this represents a relatively short synthetic route, the glycosylation reaction is poorly stereoselective $(\alpha / \beta=0.6 / 1-3 / 1)$. In the case of sugar NDPs having 1,2-trans-glycosidic bonding, Jakeman et al. demonstrated that the stereoselectivity could be controlled by using 2-O-acylated sugar donors (Fig. 13) (45). This method was used to provide glycosyltransferase substrates 51, including GDP- $\alpha$-D-mannose, in acceptable yields (29-35\%) with complete $\alpha$-stereoselectivity. Following this positive result, Klaffke et al. investigated glycosylation with 1,2-anhydrosugar donors $\mathbf{5 2}$ (Fig. 14), but found that these donors $\mathbf{5 2}$ gave poor stereoselectivity $(\alpha / \beta=1 / 1)$ in the glycosylation reaction (46). Hanessian et al. reported the synthesis of UDP- $\alpha$-D-glucose and -
NDP誘導体 44 は酵素触媒型ポリマー化における連鎖停止剂 として用いることが期待される。

\section{NDPのグリコシル化によるNDP糖の合成}

上述したピロリン酸形成反応を経る手法で用いられる糖 一リン酸と比べ、単糖基質は入手容易であるためにNDPの グリコシル化は直接的な糖NDPの合成法と言える。Hindsgaulのグループによって初めて糖NDP合成の直接的なアプ ローチが開発された $(43,44)$ 。図 12 に示すように、無保護単 糖45から容易に調製されるO-TMS 化されたヨウ化グリコシ ド 46 とUDPテトラブチルアンモニウム塩 47 との縮合反応、 続いて得られた生成物を TBAFによる脱シリル化で対応する 糖UDP 48 を良い収率（30-49\%）で合成した。本方法は合成 行程が比較的短いが、そのグリコシル化反応は低い立体選択 性 $(\alpha / \beta=0.6 / 1-3 / 1)$ であった。Jakemanらは1,2-trans-グリコ シド結合を有する糖NDPの合成に限り、2-O-アシル化糖供 与体49の利用で立体制御できることを明らかにした（図 13） (45)。本方法を用いて、GDP- $\alpha$-D-マンノースを含む糖転移 酵素基質 51 を中程度の収率（29-35\%）で $\alpha$ 選択的に合成し た。このポジティブな結果を受けKlaffkeらは1,2-アンヒドロ 糖供与体 52 の利用を試みたが（図 14）、そのグリコシル化反 応は低い立体選択性（ $\alpha / \beta=1 / 1 ）$ を与える結果となった $(46)$ 。 Hanessian らは無保護 $\beta$-MOP グリコシド 55 と酸性型UDP 56

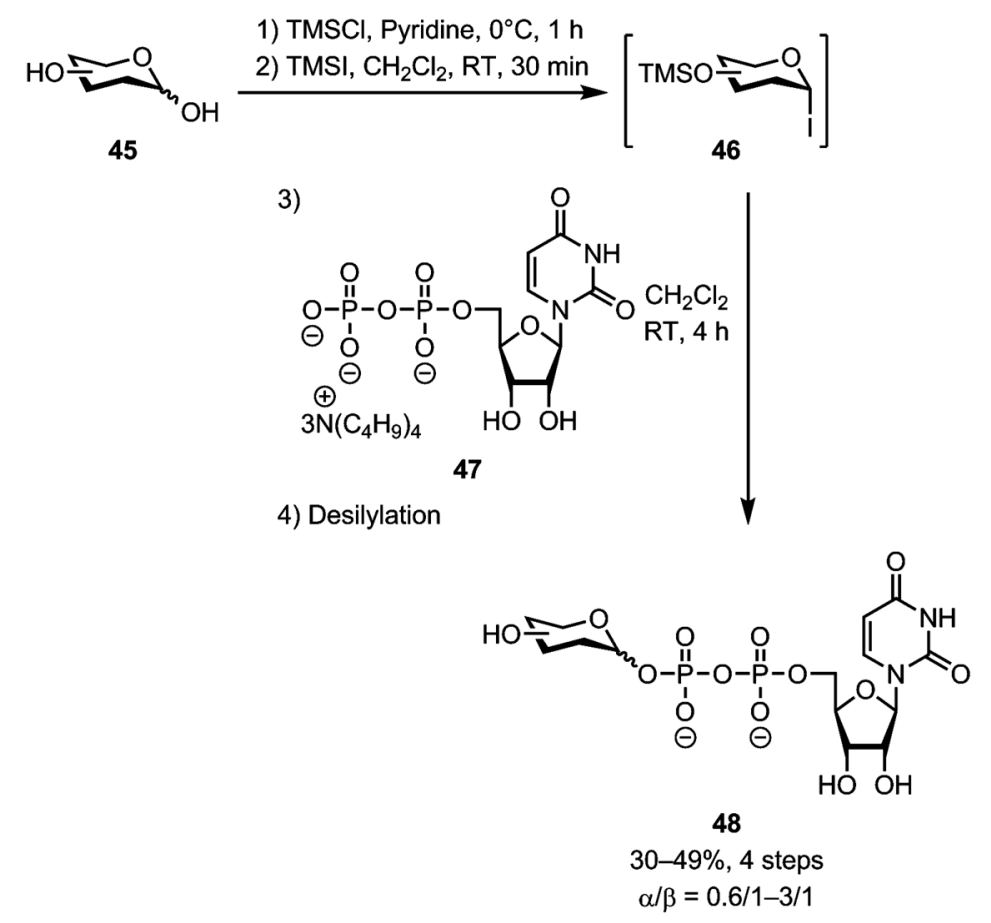

Fig. 12. Glycosylation of UDP (47) with $O$-TMS protected glycosyl iodides (46). 

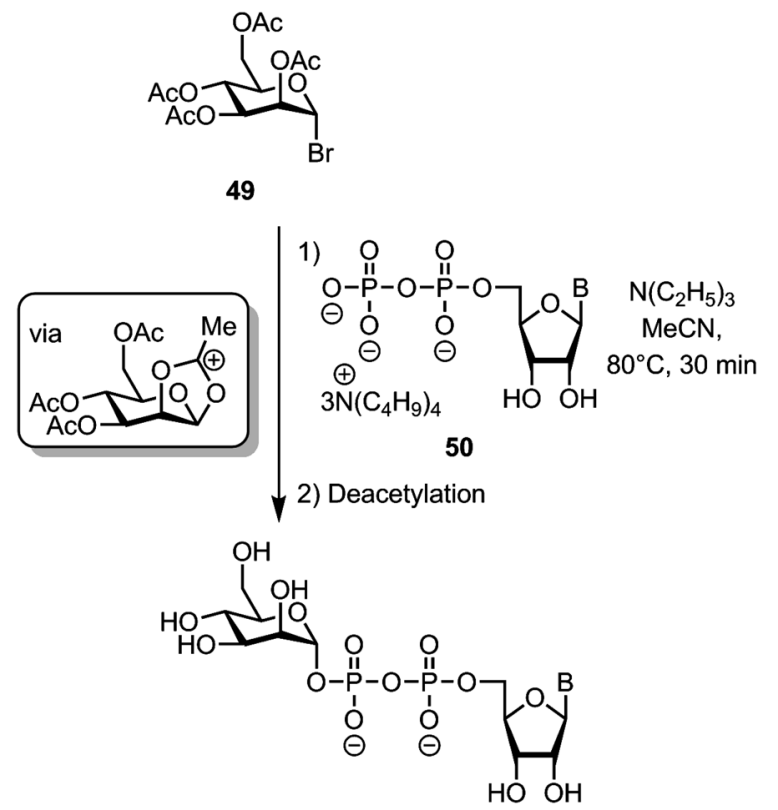

51

$29-35 \%, 2$ steps $\alpha$ only
Fig. 13. Glycosylation of UDP (50) with 2-O-aceylated mannosyl bromide (49).

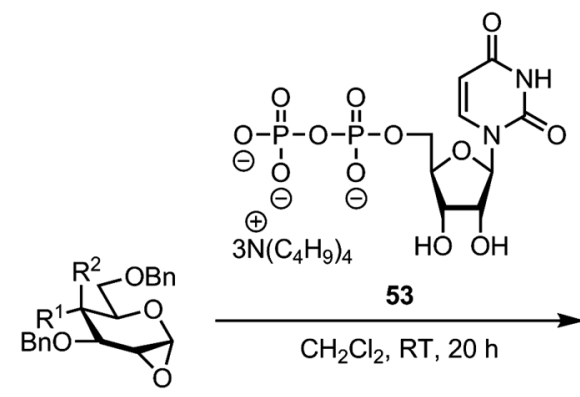

52

Glc: $\mathrm{R}^{1}=\mathrm{OH}, \mathrm{R}^{2}=\mathrm{H}$

Gal: $\mathrm{R}^{1}=\mathrm{H}, \mathrm{R}^{2}=\mathrm{OH}$

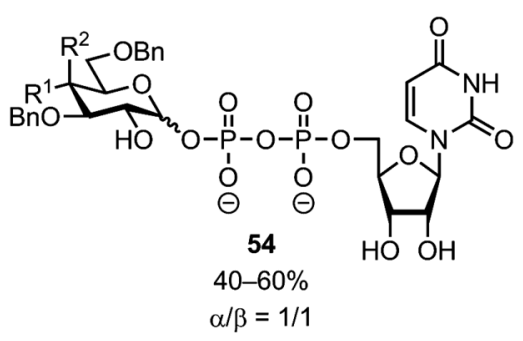

Fig. 14. Glycosylation of UDP (53) with 1,2-anhydrosugar donors (52).

galactose $\mathbf{5 7}$ yields with the desired $\alpha$-selectivity by condensation reactions between unprotected $\beta$-3-methoxy-2-pyridyl ( $\beta$-MOP) glycoside 55 and acidic UDP 56 (Fig. 15) (47). Although this method has not been applied to the synthesis of other sugar NDPs, it represents a unique one-step synthetic approach as it does not use any protecting groups.

\section{Conclusion}

In this review, recent progress in the chemical synthesis of sugar NDPs is summarized. Although both synthetic methods by pyrophosphate formation and glycosylation have developed and improved, a few problems remain. First, most synthetic schemes require deprotection manipulation in the final step, which is associated with increased product decomposition and decreased

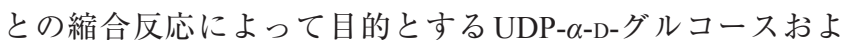
びガラクトース 57 を $\alpha$ 選択的に合成できることを見出した （図 15）（47）。他の糖NDPの合成への応用はされていないが、 本方法は保護基を用いないユニークな一段階合成アプローチ と言える。

D. まとめ

本稿では糖NDP化学合成の最近の進展について紹介し た。これまでにピロリン酸結合形成を用いた合成法ならびに グリコシル化を用いた合成法が開発・改良されてきたが、未 だ解決すべき問題がいくつか存在している。まず、合成法の 多くは最終段階で脱保護が必要であり、その段階で生成物の 


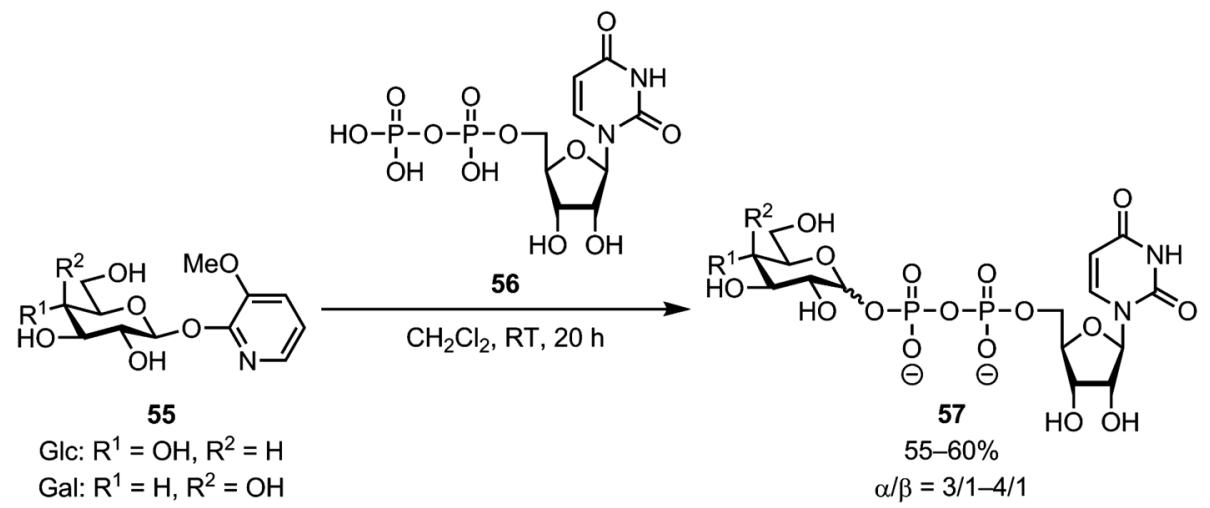

Fig. 15. Glycosylation of UDP (56) with $\beta$-MOP glycosides (55).

yields. Additionally, poor reproducibility is often encountered as dehydrated conditions are needed during the coupling reactions. In recent years, a number of promising approaches have emerged that can potentially overcome these limitations. Further studies on the chemical synthesis of sugar nucleotides are expected to facilitate the efficient synthesis of glycoconjugates (glycolipids and glycoproteins) and also help elucidate the role of glycans and glycosyltransferases in biological events.

\section{Acknowledgments}

The author is deeply grateful to Prof. Ole Hindsgaul and Prof. Monica M. Palcic for their helpful support and suggestions.
分解、収率の低下を招いてしまう。次に、カップリング反応 で脱水条件が必須であるために再現性がしばしば得られな い。近年、これら欠点を克服することができる合成法が報告 されている。糖ヌクレオチドの化学合成に向けたさらなる研 究は糖複合体（糖脂質、糖タンパク質）の効率的な合成が行 えることに加え、生命現象における糖鎖や糖転移酵素の働き を理解する手助けにもなりうると期待される。

\section{謝 辞}

多くのご支援、ご助言を賜りましたOle Hindsgaul教授、 Monica M. Palcic 教授に厚く御礼申し上げます。

\section{References}

1. Wang, C.-C., Lee, J.-C., Luo, S.-Y., Kulkarni, S. S., Huang, Y.-W., Lee, C.-C., Chang, K.-L., and Hung, S.-C. (2007) Nature 446, 896-899.

2. Imamura, A., Ando, H., Ishida, H., and Kiso, M. (2008) Heterocycles 76, 883-908.

3. Manabe, S., Ishii, K., and Ito, Y. (2008) Trends Glycosci. Glycotechnol. 20, 187-202.

4. Yu, B., and Sun, J. (2010) Chem. Commun. (Camb.) 46, 4668-4679.

5. Ishiwata, A., Lee, Y. J., and Ito, Y. (2010) Org. Biomol. Chem. 8, 3596-3608.

6. Hanashima, S. (2011) Trends Glycosci. Glycotechnol. 23, 111-121.

7. Plante, O. J., Palmacci, E. R., and Seeberger, P. H. (2001) Science 291, 1523-1527.

8. Kröck, L., Esposito, D., Castagner, B., Wang, C.-C., Bindschädler, P., and Seeberger, P. H. (2012) Chem. Sci. 3, 1617-1622.

Palcic, M. M. (1999) Curr. Opin. Biotechnol. 10, 616-624.

10. Xu, Y., Masuko, S., Takieddin, M., Xu, H., Liu, R., Jing, J., Mousa, S. A., Linhardt, R. J., and Liu, J. (2011) Science 334, 498-501.

11. Taniguchi, N., Honke, K., and Fukuda, M. (2001) Handbook of Glycosyltransferases and Related Genes.

12. Wagner, G. K., Pesnot, T., and Field, R. A. (2009) Nat. Prod. Rep. 26, 1172-1194.

13. Chambers, R. W., and Khorana, H. G. (1958) J. Am. Chem. Soc. 80, 3749-3752.

14. Chambers, R. W., and Moffatt, J. G. (1958) J. Am. Chem. Soc. 80, 3752-3756.

15. Moffatt, J. G., and Khorana, H. G. (1958) J. Am. Chem. Soc. 80, 3756-3761.

16. Roseman, S., Distler, J. J., Moffatt, J. G., and Khorana, H. G. (1961) J. Am. Chem. Soc. 83, 659-663.

17. Chapeau, M.-C., and Frey, P. A. (1994) J. Org. Chem. 59, 6994-6998.

18. Reck, F., Marmor, S., Fisher, S., and Wuonola, M. A. (2001) Bioorg. Med. Chem. Lett. 11, 1451-1454.

19. Zamyatina, A., Gronow, S., Puchberger, M., Graziani, A., Hofinger, A., and Kosma, P. (2003) Carbohydr. 338, $2571-2589$.

20. Graziani, A., Zamyatina, A., and Kosma, P. (2004) Carbohydr. 339, 147-151.

21. Beaucage, S. L., and Iyer, R. P. (1992) Tetrahedron 48, 2224-2311.

22. Wittmann, V., and Wong, C.-H. (1997) J. Org. Chem. 62, 2144-2147.

23. Tsukamoto, H., and Kahne, D. (2011) Bioorg. Med. Chem. Lett. 21, 5050-5053.

24. Sun, Q., Li, X., Sun, J., Gong, S., Liu, G., and Liu, G. (2014) Tetrahedron 70, 294-300.

25. Simon, E. S., Grabowski, S., and Whitesides, G. (1990) J. Org. Chem. 55, 1834-1841.

26. Baisch, G., and Öhrlein, R. (1997) Bioorg. Med. Chem. 5, 383-391. 
27. Takaku, H., Sato, J., Ishida, H., Inazu, T., Ishida, H., and Kiso, M. (2006) Glycoconj. J. 23, 565-573.

28. Ko, H., Fricks, I., Ivanov, A. A., Harden, T. K., and Jacobson, K. A. (2007) J. Med. Chem. 50, 2030-2039.

29. Tanaka, H., Yoshimura, Y., Jörgensen, M. R., Cuesta-Seijo, J. A., and Hindsgaul, O. (2012) Angew. Chem. Int. Ed. 51, 11531-11534.

30. Wang, S., Tanaka, H., Hindsgaul, O., Lam, J. S., and Brockhausen, I. (2013) Bioorg. Med. Chem. 23, 3491-3495.

31. Snitynsky, R. B., and Lowary, T. L. (2004) Org. Lett. 16, 212-215.

32. Bogachev, V. S. (1996) Bioorg. Chem. 22, 599-604.

33. Mohamady, S., and Taylor, S. D. (2011) J. Org. Chem. 76, 6344-6349.

34. Marlow, A. L., and Kiessling, L. L. (2001) Org. Lett. 3, 2517-2519.

35. Timmons, S. C., and Jakeman, D. L. (2008) Carbohydr. Res. 343, 865-874.

36. Mohamady, S., Desoky, A., and Taylor, S. D. (2012) Org. Lett. 14, 402-405.

37. Meier, C. (2006) Eur. J. Org. Chem. 2006, 1081-1102.

38. Wolf, S., Zismann, T., Lunau, N., Warnecke, S., Wendicke, S., and Meier, C. (2010) Eur. J. Cell Biol. 89, 63-75.

39. Wendicke, S., Warnecke, S., and Meier, C. (2008) Angew. Chem. Int. Ed. 47, 1500-1502.

40. Wolf, S., Berrio, R. M., and Meier, C. (2011) Eur. J. Org. Chem. 2011, 6304-6313.

41. Lunau, N., and Meier, C. (2012) Eur. J. Org. Chem. 2012, 6260-6270.

42. Gold, H., van Delft, P., Meeuwenoord, N., Codée, J. D. C., Filippov, D. V., Eggink, G., Overkleeft, H. S., and van der Marel, G. A. (2008) J. Org. Chem. 73, 9458-9460.

43. Arlt, M., and Hindsgaul, O. (1995) J. Org. Chem. 60, 14-15.

44. Uchiyama, T., and Hindsgaul, O. (1998) J. Carbohydr. Chem. 17, 1181-1190.

45. Timmons, S., and Jakeman, D. L. (2007) Org. Lett. 9, 1227-1230.

46. Ernst, C., and Klaffke, W. (2001) Tetrahedron Lett. 42, 2973-2975.

47. Hanessian, S., Lu, P.-P., and Ishida, H. (1998) J. Am. Chem. Soc. 120, 13296-13300.

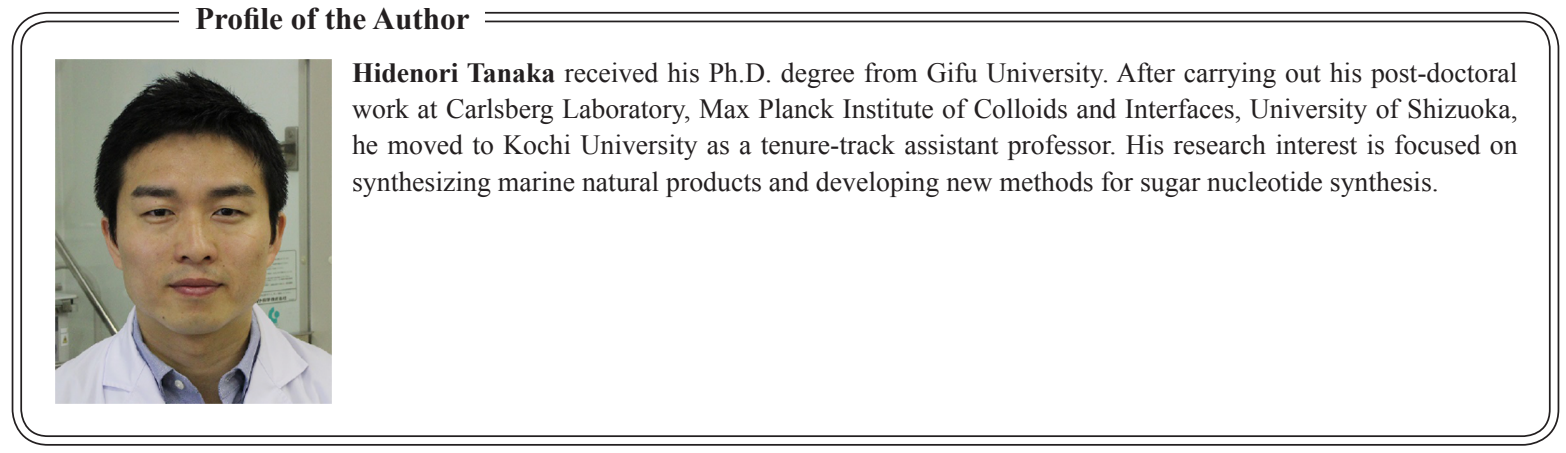

